RESEARCH ARTICLE

\title{
RATOON SYSTEMS IN TIDAL LOWLAND: STUDY OF GROUNDWATER DYNAMICS AND THE CHANGE OF NUTRIENT STATUS ON RICE GROWTH
}

\author{
Momon Sodik Imanudin ${ }^{1 *}$, Bakri $^{1}$, and Raina Jelita ${ }^{2}$ \\ ${ }^{1}$ Lecturer of Soil Department, Faculty of Agriculture, Sriwijaya University, \\ Indralaya Campus KM 32, Ogan Ilir, South Sumatera, Indonesia \\ ${ }^{2}$ Researcher at the Lowland and Coastal Data and Information Center of South Sumatera \\ Indonesia
}

Submitted: 2018-02-15 Accepted: 2018-07-16

\begin{abstract}
It has been widely known that crop cultivation in tidal lowland areas in the second crop (March-April) is not conducted by farmers in a maximum way. Thus, this research aims at investigating the dynamics of groundwater and its nutrient status condition for the purpose of supporting plant cultivation in the second crop after rice planting. The study was conducted in Banyu Urip Village, Tanjung Lago Telang II, Banyuasin. The plant used in this activity was paddy, with the treatment of a ratoon cultivation system. The ratoon system is paddy cultivation by using the first paddy planting season shoots. A urea treatment was given with a dose of $0 \mathrm{~kg} / \mathrm{ha}$ (control) and a dose of $150 \mathrm{~kg} / \mathrm{ha}$. The results of soil analysis showed that, although not significant, there was an increase in the nutrient status of the soil condition. Therefore, it can be concluded that fertilizing was considered ineffective for the system of ratoon cultivation. The study of groundwater dynamics showed that at the early phase, a groundwater table was dropped above $30 \mathrm{~cm}$ (critical) but it could increase by the rain and water retention in the canal. The average of the groundwater table during the ratoon period was at the depth of $5-30 \mathrm{~cm}$ below the soil surface, allowing it to be suitable for plant growth. The plant growth at B treatment was better and its production was $2.8 \mathrm{ton} / \mathrm{ha}$. This $2.8 \mathrm{ton} /$ ha plant production was classified as a high category for paddy with the ratoon cultivation system. There is no effect of the fertilizer treatment on the nutrient status in the soil. Moreover, the application of fertilizer did not give a significant result on the production of rice.
\end{abstract}

Keywords: tidal lowland; rice ratoon; water table; gate operation

How to Cite: Imanudin, M.S., Bakri, Jelita, R. (2018). Ratoon Systems in Tidal Lowland: Study of Ground Water Dynamics and the Change of Nutrient Status on Rice Growth. Sains Tanah Journal of Soil Science and Agroclimatology, 15(2): 93-103 (doi: 10.15608/stjssa.v15i2.18928)

Permalink/DOI: http://dx.doi.org/10.15608/stjssa.v15i2.18928

\section{INTRODUCTION}

The tidal lowland in South Sumatera Province has been reclaimed since 1970 to be developed as an agriculture area with the total wide of 301.780 hectares (Sudana, 2005). However, as time passes, there were several

\footnotetext{
* Corresponding Author:

Email:momon_unsri@yahoo.co.id
}

obstacles to the use of tidal lowlands such as chemical problems (Setyorini, Suriadikarta, \& Nurjaya, 2007) and biological problems (Saraswati \& Husen, 2007), as well as other social, institutional, organizational, infrastructural problems, and financial problem low profits. Therefore, some area used for agricultural land cannot be optimally used by the local people so that some of them were used for 
the other purposes such as palm oil and rubber plantation (Wahyunto, 2009).

The agricultural land transfer from paddy cultivation area into palm oil and rubber plantation area is very affected by $n$ the annual rice production. Therefore, there is a need to implement several strategies to increase the quantity of production per year, such as 1) increasing the wide area of production by opening new rice fields, 2) increasing land productivity, and 3) expanding the harvest area through increasing the IP (harvest index) (Erdiman, 2012).

One of the efforts to increase the production of paddy is employing the ratoon system as a method of intensification. There are several points that affect the growth of rice crops in the ratoon cultivation system, such as 1 ) the height of stems cutting from the harvest remaining, 2) variety, 3) the groundwater condition after harvesting, and 4) harvesting (Erdiman, 2012).

The potency of ratoon cultivation system is very good and it has been tested in several areas in the tropics. The benefits are earlier growing time and reducing the workforce is about $50-60 \%$. The other affecting factor is soil moisture. However, it has not been developed in the tidal lowland. The fluctuation of the groundwater level highly influences the plant growth. Paddy plants usually need $-20 \mathrm{~cm}$ to -30 $\mathrm{cm}$ water level from the ground surface. It is related to the plant roots in penetrating the soil to uptake water for the plant (Faruq, Taha, \& Prodhan, 2014). So far, this ratoon paddy cultivation technique has not been developed in the tidal lowland area. Although it has a very good potency if it is developed like in an irrigated land, the farmers just leave it without any management. Lampung BPTP (Center for Assessment of Agricultural Technology) reported that paddy production with the ratoon method reaches up to 0.7 - 5 ton ha ${ }^{-1}$ (Ernawati, Bambang W, Edwin H, \& Gohan O M, 2014).
Mareza, Djafar, Suwignyo, \& Wijaya (2016) reported that paddy production with the ratoon method in Indonesia was 1.5-2.5 ton ha- ${ }^{-1}$, whereas, in China, it is able to achieve 3.8 ton ha-1. This production diversity is influenced by the land condition and rice variety. One of the decisive factors is water availability. Concerning this point, a study about the effect of groundwater level on the growth of paddy in the ratoon method is required.

\section{MATERIALS AND METHOD}

This study was conducted at Primary canal 17 in Banyu Urip Village of Tanjung Lago subdistrict, Banyuasin Regency, in February - April 2013. The field practice was conducted by evaluating the influence of groundwater level on the growth of rice with the ratoon system. Ciherang and IR64 rice variety were used in this study. There were two land plots used for the observation area of paddy: 1) Land A with no fertilizer, located at Tertiary block number 7 (Tc7) land number 5, 2) Land B with fertilizer as many as $150 \mathrm{~kg} \mathrm{ha}^{-1}$, located at Tc7 land number 6. There were several observed parameters during this field practice, such as 1) the depth of groundwater level, 2) rainfall, 3) the height of water level in the canal, 4) plant height. Some secondary data were also used as the supporting data. The analysis of soil fertility was conducted at the Physical-Chemical Laboratory, the Soil Department of Sriwijaya University. The parameters of soil chemical and physical properties were $\mathrm{pH}, \mathrm{C}$-Organic, $\mathrm{N}$-Total, P-Bray, $\mathrm{K}-\mathrm{dd}, \mathrm{Na}, \mathrm{Ca}, \mathrm{Mg}, \mathrm{CEC}, \mathrm{Al}-\mathrm{dd}$, and soil texture.

\section{RESULT AND DISCUSSION}

\section{Characteristic of Farming System Technology}

Banyu Urip Village is one of the villages located in Telang II Delta. Administratively, Banyu Urip Village is located in Tanjung Lago Subdistrict and it has a border with the Karang Batu Village in the north, Suka Damai Village in the south, Mulia Sari Village in the east, and 
Bangun Sari Village in the west. In Banyu Urip Village, a plant cultivation pattern commonly conducted by the farmers is paddy-corn-fallow land. In the first planting season (PSI), the land is planted with a monoculture system. It is started with the pre-planting period (land cultivation) in October, planting period in November, and harvesting season in March. Meanwhile, the second planting season (PS II) is conducted in May-September and it is planted with corn. The interval time between the first and second planting period, in the late of February to the middle of April, is used by the farmers to take care of the remaining rice crops harvest and then it will produce more rice for the second harvest or better known as ratoon.

The characteristic of land used for food crop cultivation is dominated by clay fraction. Therefore, the soil permeability is relatively slow with the index as many as $1.08 \mathrm{~cm}$ hour $^{-1}$ (Santos, Fageria, \& Prabhu, 2003). Imanudin, Priatna, Wildayana, \& Armanto (2017) stated that the agricultural land in Banyu Urip Village is a wet area dominated by swamp area with very high fluctuations of water inundation. In the rain season, the waters will inundate the land as high as $+12 \mathrm{~cm}$, while in the dry season, the height of the groundwater depth will be $-112 \mathrm{~cm}$ (below the soil surface).

In the natural condition, soils in the tidal lowland area are saturated by the water or shallow inundated, along the year or in a long time, several months, or in a year (Imanudin, Armanto, Susanto, \& Bernas, 2010). In the Soil Taxonomy classification (Soil Survey Staff, 2010), the swampy area is classified as wet soils. It is characterized by aquatic conditions, which currently experiencing water saturation and continuously or periodically reduction. Nurfaijah, Setiawan, Arif, \& Widodo (2015) reported that the growth and yield of rice at groundwater depth less than $10 \mathrm{~cm}$ showed the best result and is not significantly different with the $5-7 \mathrm{~cm}$ inundation treatment. Reinforced by Setiawan,
Tyasmoro, \& Nugroho (2014), the critical value of the plant is at a water depth of $-15 \mathrm{~cm}$. In this condition, the groundwater must be immediately increased. Susilawati \& Purwoko (2014) reported that rice cultivation by the ratoon system will show maximum results when the cutting of stems is as high as $2-5 \mathrm{~cm}$ and followed by waterlogging as high as $2-5 \mathrm{~cm}$.

\section{Groundwater Table Dynamic}

Fluctuations in groundwater levels in the study area are influenced by high tide and rainfall conditions. The tide can be used as the irrigation water supply because it contains no salt unless long dry season will occur saltwater intrusion to the primary and secondary canal. Based on the type of hydro-topography class, Telang II Delta belongs to type $\mathrm{C}$ where the tide cannot enter the land, just up the secondary channel. However, the groundwater depth is still influenced by tidal fluctuations, so tidal retention can maintain the depth of the groundwater table.

Imanudin et al. (2010) wrote the description of type $\mathrm{C}$ overflow that tidal lowland has never been flooded by the highest tide of river water tidal. However, a high tide still influences the elevation of the groundwater level so that the depth of the groundwater level has never been deeper than $50 \mathrm{~cm}$ below the ground surface. The average height of the groundwater level has never been higher than $50 \mathrm{~cm}$ above the groundwater elevation (the highest).

The height of the groundwater level is highly influenced by rainfall. It is similar to the field result. The height of the groundwater level was measured by using wells. The result showed that the highest groundwater level was identified in March. The groundwater level reached $-5 \mathrm{~cm}$ from the ground level (shown in the graph in Figure 1). It is related with the high intensity of rainfall in March as presented in Figure 3, showing that the highest average rainfall was identified in March. 
This rain impacts on the groundwater level so that it becomes relatively shallow about $20 \mathrm{~cm}$ underground surfaces. In this condition, soil humidity is maintained to supply water needs for paddy plants.

In the daily rain graph (Figure 2), the calculation was conducted together with the groundwater level observation. In a direct observation, it is showed that, in March, rain happens almost every five days. The rainfall distribution during the second crop period (March-April) was sufficient to support the crop water requirement of rice.
As a comparison data, rainfall observation was also conducted at Kenten Climatology Station. The last 10 years monthly rainfall data in 2002 - 2012 was collected. The graph of annual rainfall (Figure 3) showed that March is a wet month with average rainfall volume reaches $\geq$ $400 \mathrm{ml}$ per year. Therefore, it can be interpreted that the groundwater level was determined by the volume of rainfall. However, the water condition in the land is also influenced by the tidewater.

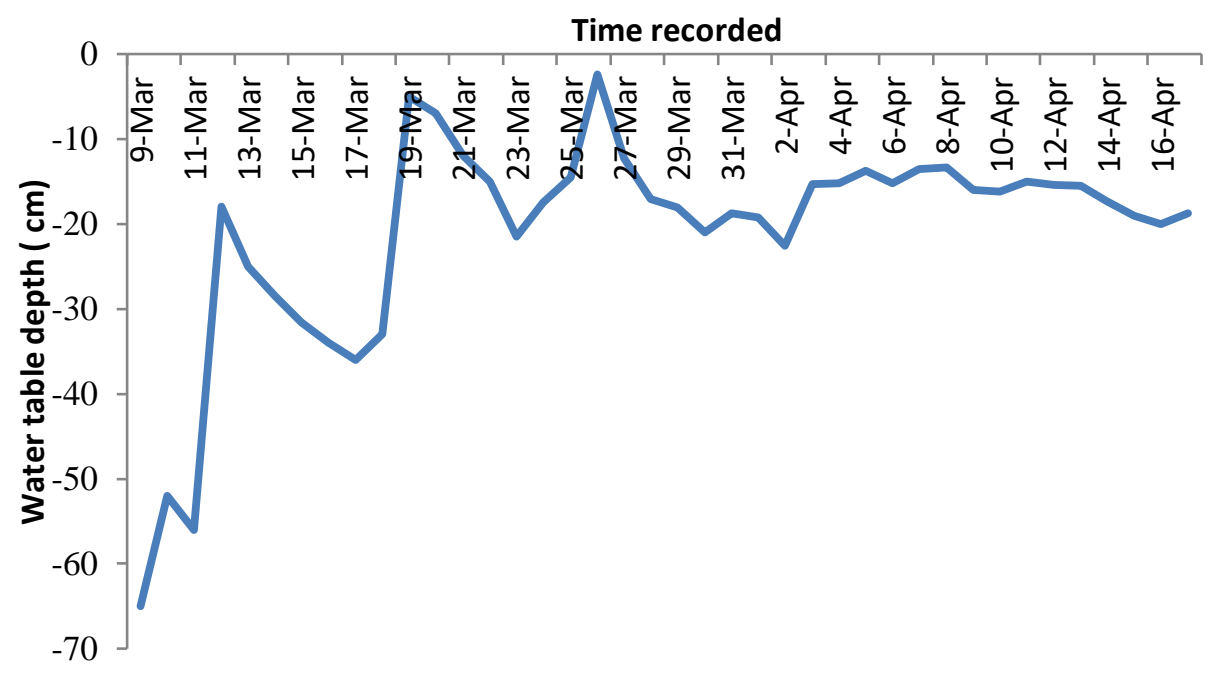

Figure 1. Daily groundwater level fluctuation, measurement was conducted by using wells

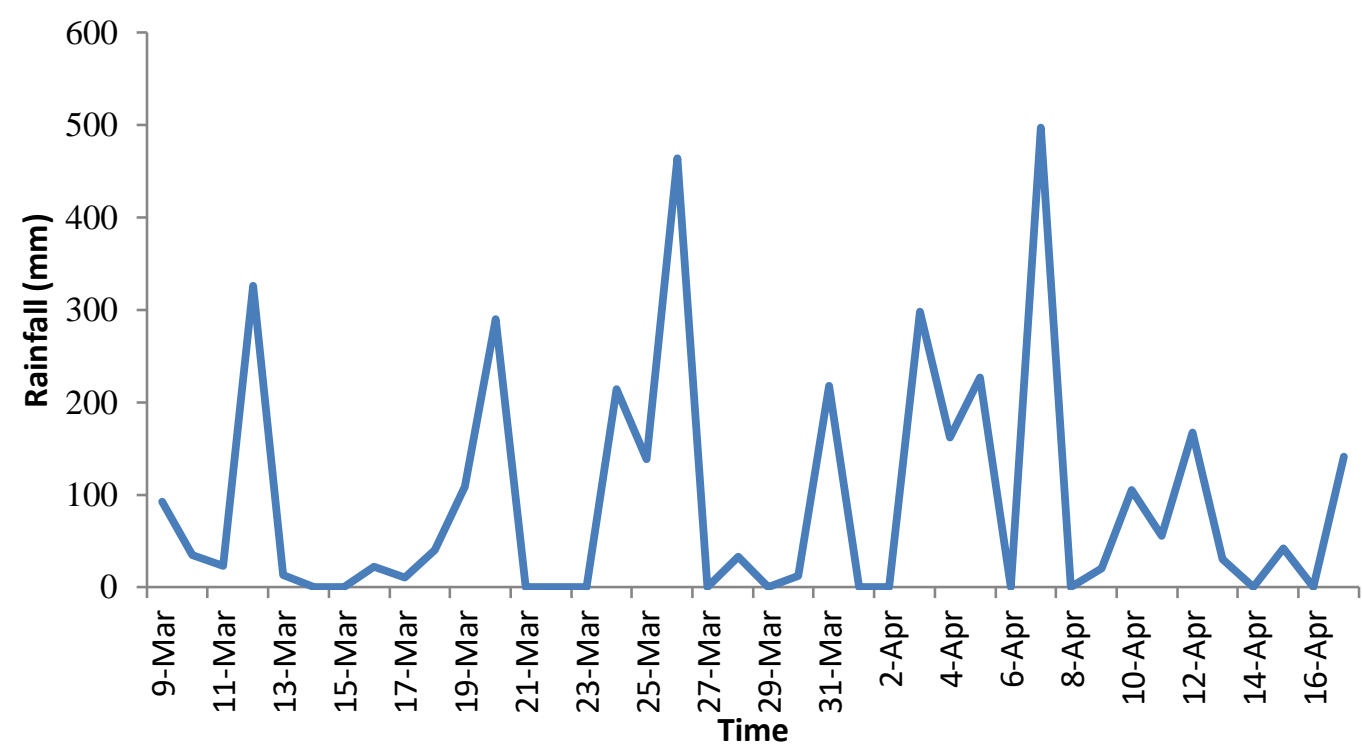

Figure 2. Daily rainfall on 23 February - 3 April 2013 


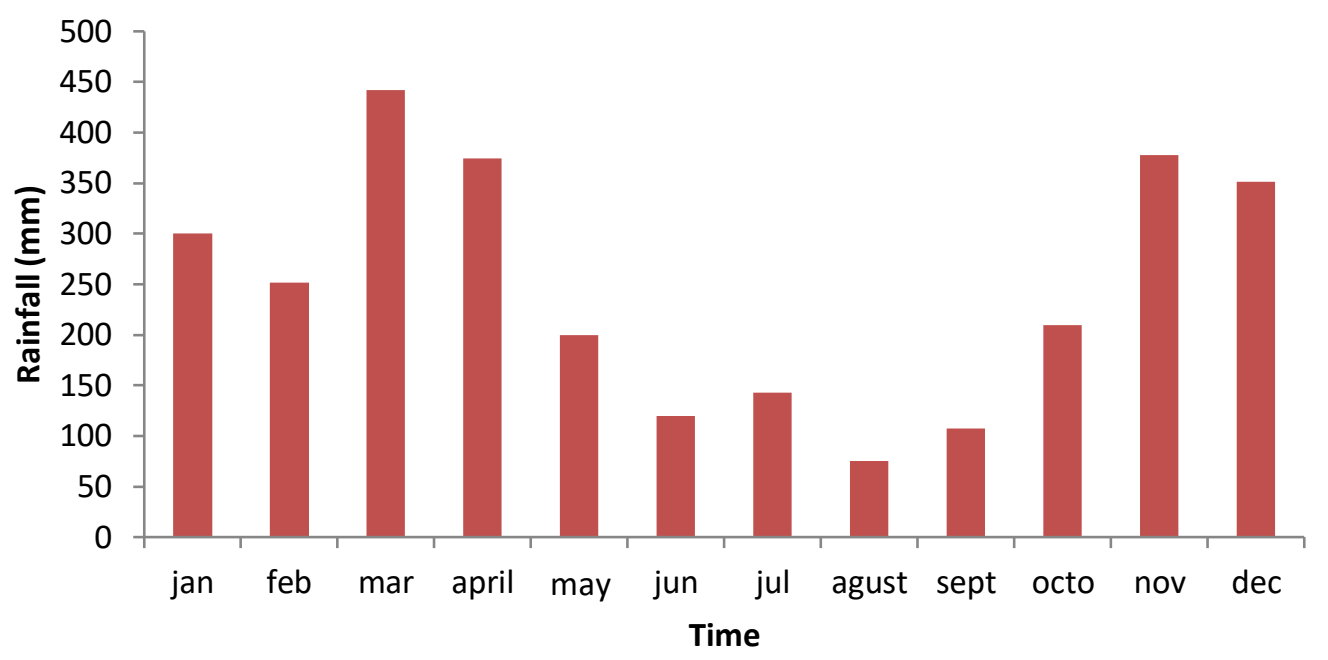

Figure 3. Annual rainfall in $2002-2012$

Groundwater is water that moves in the soil especially in the spaces between the soil pores and rock cracks (Sosrodarsono \& Takeda, 2006). Meanwhile, a groundwater level is the difference or balancing water input from the precipitation, rain that infiltrates the soil, added with condensation by the plants and soil as well as adsorption by soil, reduced by water that lost through evapotranspiration process, ground surface flow, percolation, and lateral seepage. In its mechanism, the change of groundwater level involves three main mechanisms, namely: 1) retention and water movement in the soil, 2) absorption (uptake) and water translocation in the plant, 3) evapotranspiration. Therefore, it can be interpreted that the periodical groundwater level fluctuation depends on the balance of water input and loss.

Based on Figure 1, it can be seen that the groundwater condition in the land showed groundwater depth level was strongly influenced by rainfall condition. Even though the groundwater level condition in the land has dropped to $-65 \mathrm{~cm}$ from the ground surface, its groundwater condition lifted to $-18 \mathrm{~cm}$ from the ground surface so that plants were not died due to the lack of water. With this groundwater condition from -5 to $-36 \mathrm{~cm}$ from the ground surface, the water requirement of rice plants can be fulfilled (Nurfaijah et al., 2015).

\section{Ratoon Paddy Cultivation System}

The paddy cultivation activity in Banyu Urip Village P17-6S used early age paddy variety namely IR-64. This paddy variety age is $>105$ to 124 days. The first Planting Period $I$ is conducted the farmer from October to March, while the second Planting Period II is conducted by farmers from May until September. In the Planting Period (PP I) and PP II interval from March-May, farmers plant fallow crops or continue to take care of the harvested paddy plant or grow it again to be harvested. It is better known as the ratoon paddy system. Ratoon paddy has a short life cycle. It only needs about 40 days for the rice to be harvested.

In the ratoon paddy cultivation system, the top part of harvested paddy will be cut and its plant stump will be left about $20-30 \mathrm{~cm}$ from the ground surface. However, according to Ichii (1983), ratoon cut can be conducted at about 5 $\mathrm{cm}$ and $20 \mathrm{~cm}$ from the ground surface. The water depth level is maintained at about $5 \mathrm{~cm}$. This condition is difficult if it is planted in the tidal lowland area with typology B. A research by Setiawan et al. (2014) showed that there was no interaction between the thickness of irrigation and the height of stem cutting to the plant 
growth. The ratoon plant production can reach up to 3.12 ton ha $^{-1}$ in the continuous flooding treatment.

In order to get the maximum production, a fertilizer is required because the ratoon cultivation system has low production potency. In the observation in Banyu Urip Village, there were two observed agricultural lands. Land $A$ is without fertilizer whereas Land $B$ is treated with urea fertilizer as many as $150 \mathrm{~kg} \mathrm{ha}^{-1}$. It was only given one time after paddy stem cutting.

Ratoon paddy cultivation will be continued if the shoots grown from the paddy stalks grow more than $70 \%$ (Islam, Hasanuzzaman, \& Rokonuzzaman, 2008). Paddy plants in vegetative phase require a different amount of water in accordance with the requirement. The vegetative phase of paddy plant is divided into three phases, namely: a) recovery stages and roots growth (0-10 days after planting), b) maximum growth phase of tiller (10-50 days after planting), and c) effective shooting and ineffective shooting (35-45 days after planting).

The growth and quantity of tillers are highly influenced by the cutting technique. The harvesting process in Telang is conducted using a high cutting technique. It seems that farmers have the problem with this cutting. To cut it back, farmers are constrained by time and energy. Cutting height very strong affects the ratoon paddy cultivation system, especially in its vegetative phase. The higher cutting, the fewer tillers will be but its growth will be very fast with less tiller quantity (Wasis Nyoto, 2014).

In the ratoon paddy system, the recovery phase and maximum tiller growth will not be experienced because paddy will not be transplanted and ratoon paddy will not have intensive tiller growth like newly planted paddy. Ratoon paddy has an effective shooting phase if the previous cut stems will grow new shoots and produce new leaves. The following process is the increase of the plant height shown by the lengthening of leaves.
Furthermore, paddy plants turn into generative phase. In this phase, it covers the early development of panicles (40-50 days after planting), fulfilling the phase (50-60 days after planting), and flowering (60-80 days after planting). A research by Faruq et al. (2014) showed that ratoon paddy can be harvested in 90 days, while the study conducted by Setiawan et al. (2014) revealed that it can be harvested in 96 days. This situation is characterized by the formation and growing of panicles. However, in the generative phase, ratoon paddy does not need a long time so that in 20 days paddy plants have shown panicle existence.

In the generative phase, paddy plants require a lot of water. Drought in this period will influence the formation of panicles, flower, and fertilization. In this case, it increases the sterility of plant and decreases plant production. Based on the groundwater observation in the field, the groundwater level was at -5 to $-36 \mathrm{~cm}$ from the ground surface. It is showed that paddy's water requirement was quite sufficient because paddy's roots are able to absorb water in the depth of $20-30 \mathrm{~cm}$ below the ground surface.

\section{The Effect of Fertilization on the Growth of Paddy Ratoon}

In addition to the groundwater level, fertilization also plays a role in that able to influence influencing the growth and production of paddy. As previously written, Land A was treated with no fertilizer and Land $B$ is with fertilizer as many as $150 \mathrm{~kg} \mathrm{ha}^{-1}$. The result showed that there is a difference in plant height and production between those two lands. The production of ratoon paddy at Land A was 0.8 ton ha $^{-1}$. Meanwhile, at Land $B$, the ratoon paddy production was 2.8 ton ha-1. Table 1 showed the height of the plants in the different treatment of the land. 
Table 1. Mean weekly paddy height

\begin{tabular}{ccc}
\hline Week & Land A (cm) & Land B (cm) \\
\hline 1 & 74.61 & 79.64 \\
2 & 81.60 & 95.20 \\
3 & 87.20 & 102.00 \\
4 & 100.30 & 109.90 \\
\hline
\end{tabular}

Based on Table 1 about the average weekly paddy height, it is seen that there was a difference in the plant height at Land $A$ and Land B. In the first week, its difference was $5 \mathrm{~cm}$. In the second week, its difference was $13 \mathrm{~cm}$. In the third week, its difference was $14 \mathrm{~cm}$. And in the last week, its difference was $9.6 \mathrm{~cm}$. At Land A with no fertilizer, it is showed that the height of the plants was shorter than those in Land B. However, the plants were cut in the similar height about $25 \mathrm{~cm}$ from the ground surface. The water height in each land was also similar. Having a closer look at the difference of these plants, it can be interpreted that the plants with no fertilizer were grown slower than those with fertilizer. The difference in plant height and plant production did not depend on the groundwater level because the groundwater level in the land is able to be reached by roots. However, it was caused by the difference in soil fertility.

Figure 4 showed the significant difference of ratoon paddy at Land $A$ with no fertilizer and Land $\mathrm{B}$ with fertilizer. As reported by Hanafiah (2005), $\mathrm{NH}_{4}{ }^{+}$in the urea fertilizer plays a role in composing all proteins (acids-amino acidsenzyme) and chlorophyll, coenzyme, and nucleic acids as well as growth hormones such as cytokines and auxins

Mareza et al. (2016b) reported that the application of urea fertilization with the dose of $150 \mathrm{~kg} \mathrm{ha}^{-1}$ enhances the performance of rice growth. It produced $15-16$ gr grain weight per clump. The application of fertilizer especially Nitrogen, followed by waterlogging after harvesting the main plant, increases the plant height and the productivity of tillers and rats. The growth of ratoon rice was very dependent on the dose of fertilizer given, and the ratoon response was varying with to the dose of different fertilizers. Maximum production of rice on the grain yield of ratoon crop was given by $\mathrm{N}=150$, $\mathrm{P} 2 \mathrm{O} 5=85, \mathrm{~K} 2 \mathrm{O}=90, \mathrm{~S}=13, \mathrm{Zn}=4:$ in $\mathrm{kg} \mathrm{ha}^{-1}$. However, the grain yield from ratoon crop was produced to be less than the main crop. On the other hand, the crop duration was shorter. It was a good alternative to increase cropping intensity and total rice yield (Islam et al., 2008).

The application of urea fertilizer half of the first dose of the main crop could improve the quality of the yield. The result is that the height of ratoon reaches up to $2.25-3.61 \mathrm{~m}$. Thus, the utilization of ratoon plant system and management of rice farming with ratoon system in the tidal lowland is believed to be increasing the harvesting indexes per planting season. Therefore, the rice harvest that has been done once per planting season increases to two times per season. Thus, the additional yield per planting season will be obtained. The production of ratoon rice is very seasonally dependent; this is related to the status of groundwater. However, the resulting product can make optimal land use with low production costs. The results and income of farmers per planting season are also increased since farming with the ratoon system is saving input production, cost, and time (Susilawati \& Purwoko, 2014).

Fertilization can increase the growth but a certain level, it cannot increase the production quantity. A research by (Bond \& Bollich, 2006) showed that the nitrogen application as many as 90-120 kg ha-1 was no longer able to increase paddy production. This condition was in line with the research result of Islam et al. (2008), stated that the highest paddy production with ratoon method was achieved in urea dose as many as $120 \mathrm{~kg} \mathrm{ha}^{-1}$. 


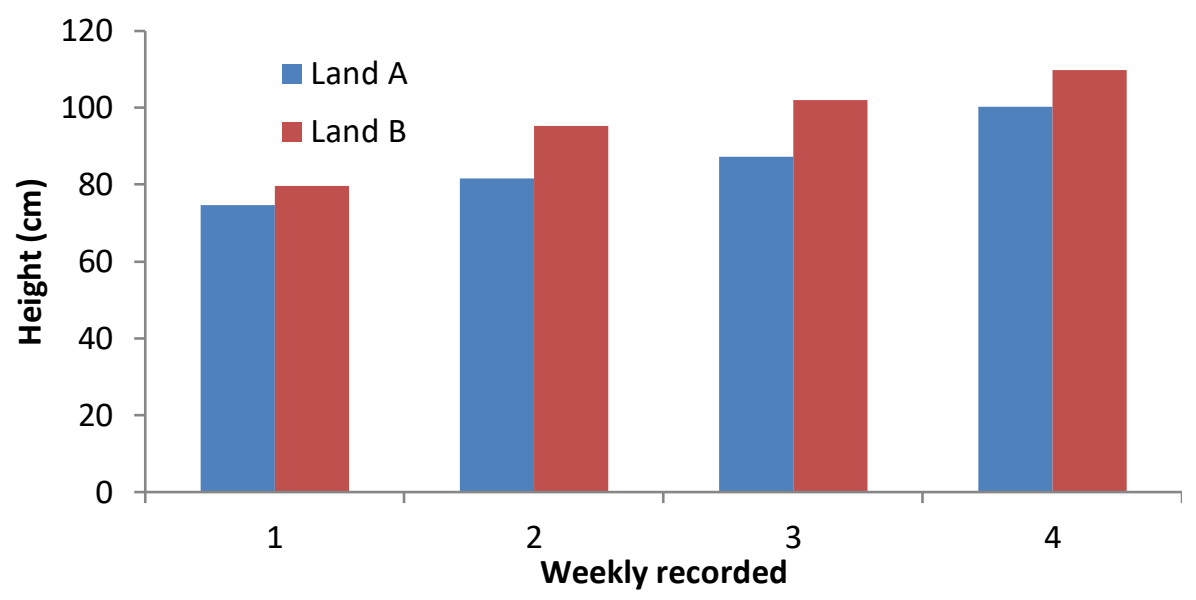

Figure 4. The weekly average height of paddy

Table 2. The result of initial and final soil analysis in the study area

\begin{tabular}{|c|c|c|c|}
\hline \multirow{2}{*}{ Type of Analysis } & \multirow{2}{*}{ Initial Soil Analysis } & \multicolumn{2}{|c|}{ Final Soil Analysis } \\
\hline & & Land A & Land B \\
\hline $\mathrm{pH} \mathrm{H}_{2} \mathrm{O}$ & 4.28 & 4.62 & 4.50 \\
\hline $\mathrm{pH} \mathrm{KCl}$ & 3.85 & 3.93 & 3.89 \\
\hline C-organic & 0.46 & 4.74 & 5.31 \\
\hline N-Total (\%) & 0.04 & 0.42 & 0.39 \\
\hline P-Bray I (ppm) & 29.25 & 25.20 & 21.45 \\
\hline $\mathrm{K}-\mathrm{dd}\left(\mathrm{me} 100 \mathrm{~g}^{-1}\right)$ & 0.26 & 0.38 & 0.32 \\
\hline $\mathrm{Na}\left(\mathrm{me} 100 \mathrm{~g}^{-1}\right)$ & 0.87 & 0.54 & 0.76 \\
\hline $\mathrm{Ca}\left(\mathrm{me} 100 \mathrm{~g}^{-1}\right)$ & 1.88 & 2.05 & 2.28 \\
\hline $\mathrm{Mg}\left(\right.$ me $\left.100 \mathrm{~g}^{-1}\right)$ & 1.20 & 0.68 & 0.55 \\
\hline $\operatorname{CEC}\left(\right.$ me $\left.100 \mathrm{~g}^{-1}\right)$ & 17.40 & 30.45 & 43.50 \\
\hline Al-dd (me $\left.100 \mathrm{~g}^{-1}\right)$ & 1.36 & 1.50 & 0.76 \\
\hline $\mathrm{H}-\mathrm{dd}\left(\mathrm{me} 100 \mathrm{~g}^{-1}\right)$ & 0.38 & 0.72 & 0.64 \\
\hline \multicolumn{4}{|l|}{ Texture } \\
\hline Sand (\%) & 22.06 & 32.64 & 30.35 \\
\hline Silt (\%) & 31.61 & 44.88 & 42.84 \\
\hline Clay (\%) & 46.33 & 22.48 & 26.81 \\
\hline
\end{tabular}

The application of urea as many as $60 \mathrm{~kg} \mathrm{~N}$ $\mathrm{ha}^{-1}$ is able to increase paddy production with ratoon method as many as 1.9 ton $\mathrm{ha}^{-1}$ on $30 \mathrm{~cm}$ stem cutting (Huossainzade, Azarpour, Doustan, Moraditochaee, \& Bozorgi, 2011). The growth and production of the plant are influenced by the fertility level and also environmental condition especially temperature and sun radiation (Oad, Cruz, Memon, Oad, \& Hassan, 2002).
Based on the analysis result at the laboratory (Table 2), shows the main problem of soil fertility is the low acidity level. Soil analysis was conducted for the initial land sample before and after the ratoon technique. The initial soil sample analysis showed that C-organic content in the soil was low as many as $0.46 \%$ while in the analyzed soil sample after ratoon technique, Corganic content increased up to more than $5 \%$. 
At Land A with no fertilizer, the content of Corganic in the soil was $4.74 \%$ while at Land $B$ with the fertilizer treatment, C-organic content was $5.31 \%$. The difference of $\mathrm{C}$-organic content in these two soil treatments was $0.57 \%$.

As showed by the analysis result, before ratoon treatment the content of $\mathrm{N}$-total was $0.04 \%$, while the content of $\mathrm{N}$-total at the land with ratoon technique increased up to $0.42 \%$ at Land $\mathrm{A}$ and 0.39 at Land B. Cation Exchange Capacity (CEC) of land also increased from 17.40

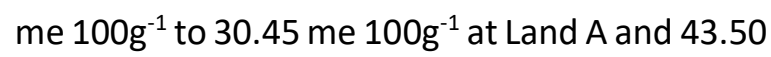
me $100 \mathrm{~g}^{-1}$ at Land $\mathrm{B}$.

The increasing of C-organic content and Cation Exchange Capacity (CEC) content at these two lands were different. The increasing of $C$ organic content and Cation Exchange Capacity (CEC) index were possibly caused by urea fertilizer treatment. However, $\mathrm{N}$-total at Land A was higher than Land $\mathrm{B}$. It was because Al-dd at Land $A$ is $0.74100 \mathrm{~g}^{-1}$ higher than at Land $B$. The increasing of chemical content in the soil was not only caused by the fertilizer treatment but also triggered by the additional of litter component in the plant. If it was only seen from the height of plants, the fertilizer treatment to the plant height was directly proportional. However, the fertilizer treatment was inefficient because the production cost was not balanced with the production result. The production result of paddy with ratoon method was only one-third of normal production.

\section{CONCLUSION AND RECOMMENDATION}

The fluctuation of groundwater table in tertiary block (on the farm) is highly determined by the rainfall in this area. However, the water availability in a canal is able to keep the groundwater table near the root zone to fulfill crop water requirement.

The condition of the groundwater table in the rice fields in Banyu Urip Village was near the soil surface because during the rainy season it is able to reach $-5 \mathrm{~cm}$ from the ground surface.
Paddy roots are able to reach waters in the depth of $20 \mathrm{~cm}$ from the ground surface and groundwater table under 5 to $36 \mathrm{~cm}$ from the ground surface. It is shown that the water requirement could be fulfilled.

The production of paddy field with ratoon method was influenced by the urea fertilizer treatment. It was shown by the production difference of Land A ( 0.8 ton ha ${ }^{-1}$ ) and Land B (2.8 ton ha-1).

The fertilizer treatment for paddy plants with ratoon method was ineffective because if it was compared to the land with no fertilizer, it only increased C-organic content as many as 0.5\% and Cation Exchange Capacity (CEC) contents as many as 13.00 me $100 \mathrm{~g}^{-1}$.

It is suggested that plant cultivation with ratoon method should be conducted in wet season such as March. It is intended to maintain the height level of the groundwater table so plant water requirement can be fulfilled. A balanced fertilizer treatment should be conducted in paddy cultivation with ratoon method in order to get a balanced production with fertilizer cost. A further research about fertilizer application dose is required in order to increase the production of paddy with ratoon system.

\section{REFERENCES}

Bond, J. A., \& Bollich, P. K. (2006). Ratoon Rice Response to Nitrogen Fertilizer. Plant Health Progress, 5(1). http://doi.org/10.1094/CM-2006-0523-02RS

Dariah, A., \& Agus, F. (2007). Pengelolaan Sifat Fisik Tanah Sawah Bukaan Baru. In Prosiding Tanah Sawah Bukaan Baru (pp. 107-130). Bogor: Balai Besar Litbang Sumberdaya Lahan Pertanian. BBLSLP.

Erdiman. (2012). Teknologi Salibu Meningkatkan Produktivitas Lahan (3-6 Ton/Ha/Tahun) dan Pendapatan Petani (Rp.15-25 Juta/Tahun). TEKNOLOGI SALIBU MENINGKATKAN PRODUKTIVITAS LAHAN ( 
3 DAN PENDAPATAN PETANI ( Rp - 165$)$. T $2 O N 5$ - /HA/TT JU A/ AH AH T U UN N ). Padang, Sumatera Barat.

Ernawati, P. :, Bambang W, Edwin H, \& Gohan O M. (2014). Teknologi Budidaya Pada Sawah Sistem Ratun. Lampung. Retrieved from http://lampung.litbang.pertanian.go.id/ind /images/stories/leaflet2015/ratunpadi.pdf

Faruq, G., Taha, R. M., \& Prodhan, Z. H. (2014). Rice ratoon crop: A sustainable rice production system for tropical hill agriculture. Sustainability, 6, 5785-5800. http://doi.org/10.3390/su6095785

Hanafiah, K. A. (2005). Dasar-dasar ilmu tanah. PT RajaGrafindo Persada. Retrieved from https://books.google.co.id/books/about/D asar_dasar_ilmu_tanah.html?id=AkbRnQA ACAAJ\&redir_esc=y

Huossainzade, A., Azarpour, E., Doustan, H. Z., Moraditochaee, M., \& Bozorgi, H. R. (2011). Management of Cutting Height and Nitrogen Fertilizer Rates on Grain Yield and Several Attributes of Ratoon Rice (Oryza sativa L.) In Iran. World Applied Sciences Journal, 15(8), 1089-1094. Retrieved from https://pdfs.semanticscholar.org/54a3/03 8c79ec02aa85d834360d8bed25866a0469. pdf

Ichii, M. (1983). The Effect of Water Management On Ratoon Ability of Rice Plants. Tech Bull Fac Agr, 34(2), 123-128.

Imanudin, M. S., Armanto, M. E., Susanto, R. H., \& Bernas, S. T. (2010). Water Status Evaluation on Tertiary Block for Developing Land Use Pattern and Water Management Strategies in Acid Sulfat Soil of Saleh Tidal Lowland Reclamation Areas of South Sumatera. AGRIVITA, Journal of Agricultural Science, 32(3), 241-253. http://doi.org/10.17503/AGRIVITA.V32I3.1 6

Imanudin, M. S., Priatna, S. J., Wildayana, E., \& Armanto, M. E. (2017). Variability of Ground Water Table and Some Soil Chemical Carachteristic on Tertiary Block of Tidal Lowland Agriculture South Sumatera Indonesia. Sains Tanah, 14(1), 7-17.
Islam, M. S., Hasanuzzaman, M., \& Rokonuzzaman, M. (2008). Ratoon Rice Response to Different Fertilizer Doses in Irrigated Condition. Agriculturae Conspectus Scientificus, 73(4), 197-202. Retrieved from https://acs.agr.hr/acs/index.php/acs/articl e/view/23

Mareza, E., Djafar, Z. R., Suwignyo, R. A., \& Wijaya, A. (2016a). Pertumbuhan dan Produksi Ratun berbagai Varietas Padi Potensial Pasang Surut dengan Potensi Ratun yang Berbeda (The Growth and Production of Various Tidal Rice Varieties with Different Potential Ratoon). In Prosiding Seminar Nasional Lahan Suboptimal 2016 (Vol. 1, pp. 979-587). Palembang: Pusat Unggulan Riset dan Pengembangan Lahan Suboptimal, Universitas Sriwijaya.

Mareza, E., Djafar, Z. R., Suwignyo, R. A., \& Wijaya, D. A. (2016b). Morfofisiologi Ratun Padi Sistem Tanam Benih Langsung di Lahan Pasang Surut. Jurnal Agronomi Indonesia (Indonesian Journal of Agronomy), 44(3), 228-234. http://doi.org/10.24831/jai.v44i3.12908

Nurfaijah, Setiawan, B. I., Arif, C., \& Widodo, S. (2015). Sistem Kontrol Tinggi Muka Air Untuk Budidaya Padi. Jurnal Irigasi, 10(2), 97-110. http://doi.org/10.31028/ji.v10.i2.97-110

Oad, F. C., Cruz, P. S., Memon, N., Oad, N. L., \& Hassan, Z. U. (2002). Rice Ratooning Management. Journal of Applied Sciences, 2, 29-35. http://doi.org/10.3923/jas.2002.29.35

Santos, A. B., Fageria, N. K., \& Prabhu, A. S. (2003). Rice Ratooning Management Practices for Higher Yields. Communications in Soil Science and Plant Analysis, 34(5-6), 881-918. http://doi.org/10.1081/CSS-120018981

Saraswati, R., \& Husen, E. (2007). Prospek Penggunaan Pupuk Hayati pada Sawah Bukaan Baru. In Lahan Sawah Bukaan Baru (pp. 151-173). Bogor: Balai Penelitian Tanah,Kementerian Pertanian. Retrieved 
from

http://balittanah.litbang.pertanian.go.id/d ocument.php?folder=ind/dokumentasi/bu ku/buku lahan sawah bukaan baru\&filename=08pupukhayati_rasti\&ext= pdf

Setiawan, A., Tyasmoro, S. Y., \& Nugroho, A. (2014). INTERMITTENT IRRIGATION AND CUTTING HEIGHT ON RATOON RICE (Oryza sativa L.). AGRIVITA, Journal of Agricultural Science, 36(1), 72-80. http://doi.org/10.17503/AGRIVITA.V36I1.3 31

Setyorini, D., Suriadikarta, D. A., \& Nurjaya. (2007). Rekomendari Pemupukan Padi di Lahan Sawah Bukaan Baru. In ahan Sawah Bukaan Baru (pp. 77-106). Bogor: Balai Penelitian Tanah,Kementerian Pertanian. Retrieved from http://balittanah.litbang.pertanian.go.id/i nd/dokumentasi/buku/buku lahan sawah bukaan baru/05pemupukan_diah.pdf?secure=true

Soil Survey Staff. (2010). Keys to Soil Taxonomy (11th ed.). Washington: United States Department of Agriculture, Natural Resources Conservation Service. Retrieved from https://www.nrcs.usda.gov/Internet/FSE_ DOCUMENTS/nrcs142p2_050915.pdf

Sosrodarsono, S., \& Takeda, K. (2006). Hidrologi untuk pengairan. Jakarta: Pradnya Paramita. Retrieved from http://www.nlb.gov.sg/biblio/4194217
Sudana, W. (2005). Potensi dan Prospek Lahan Rawa sebagai Sumber Produksi Pertanian. Analisis Kebijakan Pertanian, 3(2), 141151. http://doi.org/10.21082/AKP.V3N2.2005.1 41-151

Susilawati \& Purwoko, B. S. (2014). PENGUJIAN VARIETAS DAN DOSIS PUPUK UNTUK MENINGKATKAN PERTUMBUHAN DAN HASIL RATUN-PADI DI SAWAH PASANG SURUT. Jurnal Pengkajian Dan Pengembangan Teknologi Pertanian, 15(1), 47-54. http://doi.org/10.21082/JPPTP.V15N1.201 2.P\%P

Wahyunto. (2009). Lahan Sawah di Indonesia Sebagai Pendukung Ketahanan Pangan Nasional (Paddy fields in Indonesia as a back stopped for national food security). Informatika Pertanian, 18(2), 133-152. Retrieved from http://perpustakaan.pertanian.go.id/simp ertan_litbang/katalog/majalah/all/informa tika-pertanian/18/2/2009/lahan-sawah-diindonesia-sebagai-pendukung-ketahananpangan-nasional

Wasis Nyoto 2014. Response of the ratoon rice (Oryza sativa L.) system to the height of pruning and dosing of mycoriza in the vegetative phase. Skripsi. National Veteran University. (Not published) 